\title{
The effect of talent management factors on teacher's leadership at the secondary schools
}

\author{
Noor Haslinda Harun ${ }^{a *}$, Nik Hasnaa Nik Mahmood ${ }^{\text {a }}$ and Siti Amirah Othman ${ }^{\mathrm{a}}$
}

${ }^{a}$ Razak Faculty of Technology and Informatics, Universiti Teknologi Malaysia, 54100 UTM Kuala Lumpur, Malaysia

\begin{tabular}{l}
\hline C H R O N I C L E \\
\hline Article history: \\
Received: June 92019 \\
Received in revised format: July 9 \\
2019 \\
Accepted: July 29, 2019 \\
Available online: \\
July 30, 2019 \\
\hline Keywords: \\
Talent management \\
Teacher leadership \\
Development \\
Professional development \\
Teacher quality
\end{tabular}

\section{Introduction}

One of the major tasks of Malaysia Ministry of Education (MOE) in raising education quality is to ensure all aspirations, namely system and students in the Malaysia Education Blueprint 2013-2025 (MEB 20132025) are attained. This entails a huge commitment from all parties in MOE especially teachers and school leaders. School is an organization that is an example of society. The success of a school depends on the leadership of teachers practised in schools. Effective leadership development will lead to a positive impact on communities and communities at all levels. Quality leadership is a contributing factor for the success of the school in leading the community. Furthermore, successful teacher leadership can create a conducive working climate that indirectly improves school achievement. Teacher leadership can produce more skilled people, teachers and become the catalyst for brilliant and distinguished students. The existence of talent management terms arises when there is a competition among organizations to obtain quality workers. It was developed around the mid-1990's and has been warmly spoken in the 21st century. Iles

\footnotetext{
* Corresponding author.

E-mail address: aslynda2329@gmail.com (N. H. Harun)

(C) 2020 by the authors; licensee Growing Science, Canada doi: $10.5267 /$ j.msl.2019.7.039 
et al. (2010) state that the term management of talent becomes increasingly popular when it is included in a report written by Michaels et al. (2001) of Mc Kinsey \& Company. The field of talent management becomes the scope of discussion namely in the education sector at the school level. Talent management by analysis has undergone evolution and integration in various elements in human resources. As it entered the 21 st century, a key focus in human resource management expanded to address strategic issues (Ab Samad et al., 2017). Among them is to make the recruitment process more efficient and effective based on one's skills and competencies. In addition, it can develop leaders to enhance the culture, strengthen the value and availability of co-leaders. Furthermore, it identifies the existing skills gaps for development to be efficiently and Managing employees regularly and consistently.

\section{Literature review}

Some studies have paid attention to this area in the higher education sector (Riccio, 2010; Behrstock \& Clifford, 2010). Little is understandable about how talent management will influence other strategic objectives such as developing a high-performance learning environment and adding value to the academy brand (Davies and Davies, 2011) such as high-performance schools. In line with Charan et al. (2011), talent management is defined as a leadership succession process within an organization or process in which the organization ensures leadership development as well as important skills in the future through the establishment of leadership channels.

\subsection{Underpinning theory (Path Goal Theory)}

The path-goal leadership theory by House (1971) is based on the motivational theories of goal setting and expectation theory. According to this theory, leaders are responsible for increasing the motivation of followers to achieve personal and organizational goals. Motivation will increase when the leader explains the path to go through to achieve the objectives that the followers expect. Goal paths mean that leaders work together with followers to help them identify and learn behaviour that will lead to work achievement and impact the employees and organizations. Based on the goal-line theory, employees will be motivated when these three conditions are fulfilled, when employees believe their ability to complete the given assignment, when employees believe that completing the task will lead to a goal when employees believe that the goal of completing the task is meaningful. Motivated workers aim the desired goal when leaders clearly define organizational goals, point out the path to goal and overcome the obstacles.

\subsection{Talent management}

Talent management is defined as a process in which the organization identifies potential employees who play a leading role in the future (Beheshtifar et al, 2012). It also focuses on developing a wider range of potential employees to fill vacancies in future organizations (Gay and Sims, 2006). Talent management according to Charan et al. (2010) is a process of replacing leadership in the organization in ensuring the development of appropriate leadership and needed for the future through a leadership preparatory channel. The concept of talent management began to be said since the competition between organizations to get qualified employees or referred to as Talent. It developed in the mid-1990s and is increasingly being highlighted in the beginning of the 21 st century. This competition is seen to continue to increase the string of higher demand for skilled and experienced workers as well as calibre. According to Bersin (2006), talent management is born from the evolution of human resources where it is a chain of business development processes, it is not a product or solution that we can buy. He attributed the evolution of human resources to three stages of human resource development, namely:

The early 1970s until the late 1980s. This stage is a term known as the management of personnel or employees only. Individuals who perform this task are usually in the personnel department. The assignment is to hire employees, pay them and make sure they get the reward they deserve. It plays a role in business travel. The early 1980s until the late 1990s. At this stage most organizations are aware that the 
role played by the personnel department is increasingly important. The concept of strategic human resources began to emerge. While most organizations appoint a vice president of human resources and play a bigger role such as hiring the right employees, developing them, helping them design the areas of work and organizational design, developing a comprehensive rewards package and becoming a centre of communication practice maintenance that helps employees be happy and satisfied. Several new systems and functions exist at this stage to support their wider and more challenging tasks, including the applicant's tracking system and employee retrieval, reward systems and learning management systems. At this stage, their role is more to business partners, beyond the previous role line that only helps business. When entering 21st century, talent management terms emerged among human resource practitioners. Whilst the main focus of human resource strategy continues, towards addressing some of the strategic issues that occur in human resource management as highlighted below:

- How can we make the recruitment process more efficient and effective by using the skills-based approaches needed to implement a task or competency based?

- How can we develop managers and leaders to enhance culture, strengthen values, and shape channels that are always capable of providing leaders?

- How can we quickly identify the skills gaps that allow training and development to be efficiently channel and how we can use this existing skills gap to retrieve the people who are really needed and meet the exact criteria?

- How can we manage employees consistently and can be measured so that all employees are organized, holding the necessary responsibilities and being paid fairly?

\subsection{Teacher leadership}

The development of teacher leadership is not just empowering teachers, but is an effort to develop leadership among teachers who are largely under-utilised. Teacher leadership can have a positive impact on school changes. Teachers' leadership development practices are a collective effort to collectively and collectively lead to the possibility of making all teachers in the future (Greenle, 2007). The development of teacher leadership is the result of an election process and formal appointment through the role of the committee chairman, chairman of the co-curricular department or heads of departments in secondary schools. Alternatively, teacher leadership may also exist informally through the influence that does not involve authorities such as leader selection by partners (Taylor et al., 2011).

There are some studies that discover that principals play an important role in developing teacher leadership capabilities in schools and influence the existence of effective schools (Harris, 2003; Katzenmeyer \& Moller, 2009; Frost \& Durrant, 2002; Leithwood et al., 1999). The National Conference on Islamic Education (2012) has concluded that the development of teacher leadership is one of the most important aspects and should be emphasized in the teaching module in the Teachers' educational institutions nationwide. There were participants who suggested that each teacher be given exposure and courses related to teacher leadership. While the study conducted by Chen et al. (2014) aims to see the extent of opportunities and opportunities for teacher leadership in school.

\section{The research model and research hypotheses}

Talent management (TM) affects teacher leadership (TL) among teachers in residential schools. In order to better understand the relationship between TM and TL in Malaysia, research hypotheses are tested as the proposed research framework as below 


\subsection{Research model}

Fig. 1 demonstrates the structure of the proposed study of this paper.

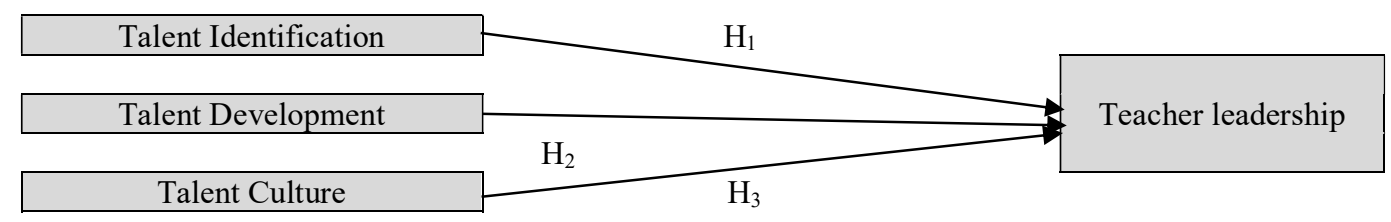

Fig. 1. The proposed study of the paper

\subsection{The relationship between talent management and teacher leadership}

Talent Management in Malaysia has begun to grow in recent times as many researchers begin to study how organizations manage the talent of their employees. In addition, the organization has also begun to set up talent management plans for them in the future. The study conducted by Sathiyabama (2017), on some teachers who attended the Leadership Development Program, NPQEL organized by Institute of Aminuddin Baki stated that the level of talent management practices and the level of leadership practice were at a high level. This survey study used questionnaires sent via email to the respondents. This study used quantitative method and administered to 363 Senior Assistant Teachers throughout Malaysia. The talent management component in his study used Gallup (2001) model which consists of five (5) dimensions comprising of, the dimension of purpose, direction dimension, motivation and authority dimension, relationship dimension and work style dimension. The findings show that there was a positive and significant relationship between talent management and leadership. While the study conducted by Shuhaida (2016) on 350 teachers and principals of High Performance Schools across Malaysia reported a positive and significant relationship between teacher talent management and teacher leadership talent. The study used a talent management model by the Malaysian GLCs. The study was conducted in mix method Survey method was conducted using questionnaire instrument and interview protocol. The questionnaire which was self-built by her using a 10-point Likert scales. Questionnaires were answered by teachers, while interviews were carried out to selected principals for High Performance Schools across Malaysia. Shuhaida's study (2016) used 5 components of talent management consisting of components identifying the potential of teacher talent, reviewing teacher performance, conducting talent development activities, using teacher talent and retaining teacher talent. Rhodes and Brundrett $(2005,2009)$ and Rhodes et al. (2008) demonstrated a significant relationship between the talent management goal and the self-perception of school leaders, getting talented staff for the right task at the time of need, and encouraging talented staff to develop themselves, commit themselves, and perform well in their work. Gay and Sims (2006) explained that talented people can produce something new and different and will be able to play a role in future leadership. It is clear that the above studies support talent management has a positive relationship with the development of teacher leadership. According to Charan et al. (2010), talent management is defined as the process of leadership succession in organization or process by which organization ensure that the leadership development and also the crucial skills in the future through the establishment of leadership pipeline. Hamzah et al. (2017) in their research stated that talent management is the process by which school develops a teacher leadership talent pool by choosing the most qualified teachers through a strategic implementation of Talent management factors. Hence this study proposes some hypotheses for this study. Literature on talent management show that most studies that have investigated the relationship between talent management and teacher leadership previous studies consider $\mathrm{H}_{1}, \mathrm{H}_{2}$ and $\mathrm{H}_{3}$ as follows:

$\mathrm{H}_{1}$ : Talent Identification positively influences teacher leadership.

$\mathrm{H}_{2}$ : Talent Development positively influences teacher leadership.

$\mathrm{H}_{3}$ : Talent Culture positively influences teacher leadership. 


\section{Methodology}

\subsection{Data collection}

This research is a quantitative approach and collecting data using a structured survey instrument. A total of 473 questionnaires were distributed among the teachers in residentials schools in East zone in Penisular Malaysia. The researchers used a 5-Likert scale and the instrument was adopted from Katzenmeyer and Moller (2009) in measuring TL and the scale proposed by Davies and Davies (2010) in measuring TM. In this study the researcher utilised the instrument by Katzenmeyer and Moller (2006) to identify seven dimensions of teacher leadership development and three dimensions for talent management.

\subsection{Statistical technique}

The data was analysed using Partial least squares structural equation modelling (PLS-SEM) a variancebased structural equation modelling. PLS was considered more suitable than CB-SEM the focus of the model is more on prediction than theory testing (Hair et al., 2017).

\subsection{Data analysis and finding}

Fig. 2 presents personal characteristics of the participants.

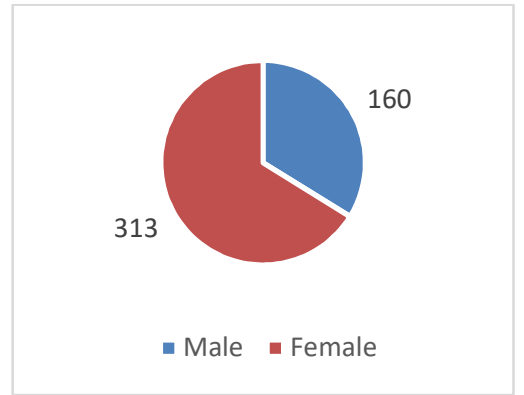

Gender

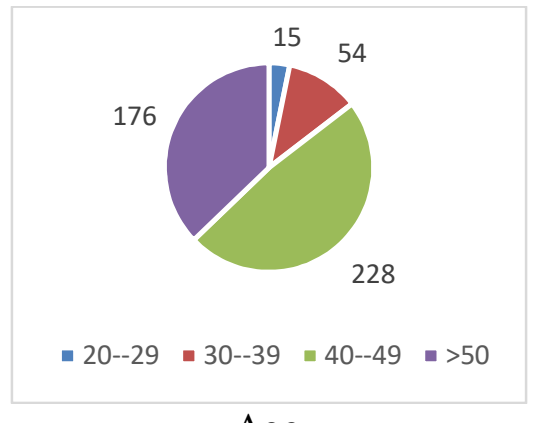

Age

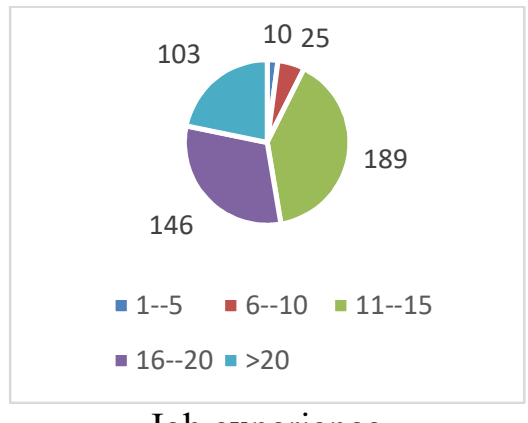

Job experience

Fig. 2. Personal characteristics of the participants

The demographic background of the respondents revealed that majority of respondents were female (66.2 $\%)$ and the remaining were male (33.8\%) and currently they are teaching at Secondary school. Most of the respondent's age were between $40-49$ years, which represents 48.2 percent of the respondents. While teachers with the age of 50 years and above amounted to 172 people representing 37.2 percent. This means the number of respondents with age 40 years and above was more than 70 percent, which means that the talent management among teachers were easy to be implemented. 83.7 percent indicated that the respondents hold the bachelor degree, followed by 16.3 percent who had a Master's degree of science. Presently, teachers have to enhance their qualification to fulfil the government requirements. In terms of work experience, 52.6 percent of the teachers had at least 15 years of job experience. There are only 7.4 percent of teachers who had fewer than 10 years of job experience, which indicates that almost half of the teachers had an expertise in their respective fields in school.

\subsubsection{Measurement model assessment}

To validate the measurement model (CFA) in SmartPLS, item loadings, average variance extracted (AVE) and composite reliability (CR) were assessed by running PLS algorithm. Figure exhibits the measurement model in SmartPLS. As shown in Table 1, all the item loadings are above the cut-off value of 
0.5 (ideally 0.7) (Fornell \& Larcker 1981; Hair et al. 2017). Moreover, all constructs had acceptable average variance extracted (AVE) ranging from 0.532 to 0.673 which are above the threshold of 0.5 (Fornell \& Larcker 1981; Hair et al. 2017) and acceptable composite reliability ranging from 0.948 to 0.979 above the cut-off point of 0.7 (Hair et al., 2009).

\section{Table 1}

Results of measurement model-Convergent validity

\begin{tabular}{lcccc}
\hline & Cronbach's Alpha & rho A & Composite Reliability & Average Variance Extracted (AVE) \\
\hline Talent Culture & 0.944 & 0.949 & 0.951 & $\mathbf{0 . 5 9 9}$ \\
Talent Development & 0.940 & 0.943 & 0.948 & $\mathbf{0 . 6 0 5}$ \\
Talent identification & 0.955 & 0.958 & 0.961 & $\mathbf{0 . 6 7 3}$ \\
Teacher Leadership Development & 0.978 & 0.979 & 0.979 & $\mathbf{0 . 5 3 2}$ \\
\hline
\end{tabular}

In addition, the discriminant validity of the constructs was measured using the square root of the average variance extracted (AVE). As shown in Table 1, the square root of average variances extracted (AVE) on the diagonals (in bold) for each construct are larger than their correlations with all the other constructs confirming the discriminant validity of the constructs. Overall, the measurement model (CFA) was assessed and confirmed by examining convergent validity and discriminant validity (Table 2).

Table 2

Discriminant Validity (n-473)

\begin{tabular}{lcccc}
\hline & Talent Culture & Talent Development & Talent identification & Teacher Leadership \\
\hline Talent Culture & 0.774 & & & \\
Talent Development & 0.828 & 0.778 & & \\
Talent identification & 0.757 & 0.786 & 0.820 & 0.729 \\
Teacher Leadership Development & 0.727 & 0.781 & 0.693 & \\
\hline
\end{tabular}

Table 3

Loading factors (n-473)

\begin{tabular}{|c|c|c|c|c|}
\hline & Talent Culture & Talent Development & Talent identification & Teacher Leadership \\
\hline $\mathrm{ABB} 1$ & & 0.686 & & \\
\hline ABB 10 & & 0.796 & & \\
\hline ABB11 & & 0.832 & & \\
\hline ABB12 & & 0.760 & & \\
\hline $\mathrm{ABB} 2$ & & 0.802 & & \\
\hline ABB3 & & 0.778 & & \\
\hline $\mathrm{ABB} 4$ & & 0.753 & & \\
\hline ABB5 & & 0.838 & & \\
\hline $\mathrm{ABB} 6$ & & 0.842 & & \\
\hline ABB7 & & 0.699 & & \\
\hline ABB8 & & 0.810 & & \\
\hline ABB9 & & 0.722 & & \\
\hline ABUB1 & 0.725 & & & \\
\hline ABUB10 & 0.796 & & & \\
\hline ABUB11 & 0.806 & & & \\
\hline ABUB12 & 0.640 & & & \\
\hline ABUB13 & 0.735 & & & \\
\hline ABUB2 & 0.729 & & & \\
\hline ABUB3 & 0.712 & & & \\
\hline ABUB4 & 0.854 & & & \\
\hline ABUB5 & 0.850 & & & \\
\hline ABUB6 & 0.846 & & & \\
\hline ABUB7 & 0.713 & & & \\
\hline ABUB8 & 0.806 & & & \\
\hline ABUB9 & 0.818 & & & \\
\hline
\end{tabular}


Table 3

Loading factors (n-473) (Continued)

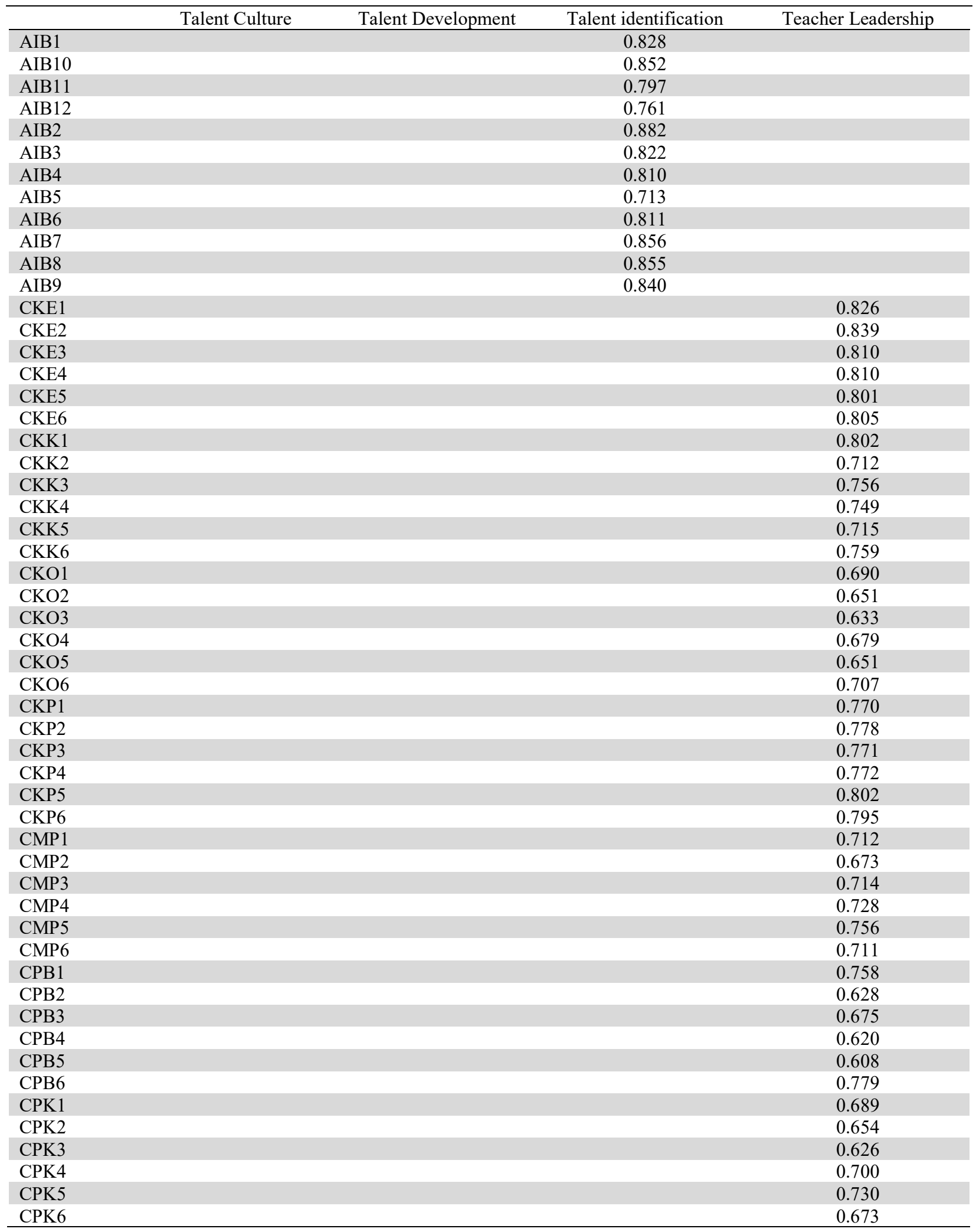




\section{Table 4}

Parameter estimates (structural model)

\begin{tabular}{llccccc}
\hline Hypotheses & Relationship & Sample & Standard & T value & P value & Decision \\
\hline $\mathrm{H}_{1}$ & Talent Culture $\rightarrow$ Teacher Leadership & 0.209 & 0.060 & 3.436 & 0.001 & Supported \\
$\mathrm{H}_{2}$ & Talent Development $\rightarrow$ Teacher leadership & 0.489 & 0.073 & 6.746 & 0.000 & Supported \\
$\mathrm{H}_{3}$ & Talent identification $\rightarrow$ Teacher Leadership & 0.151 & 0.050 & 2.967 & 0.003 & Supported \\
\hline
\end{tabular}

Note: t-value $>1.65^{*}(\mathrm{p}<0.10) ;$ t-value $>1.96^{* *}(\mathrm{p}<0.05) ;$ t-value ${ }^{* * *}>2.58(\mathrm{p}<0.01)$

\subsubsection{Assessment of Significance of the Structural Model}

The next step after ascertaining the direct relationship is to assess the structural model, a standard bootstrapping method was applied with 500 bootstrapped samples and 100 cases in SmartPLS. This was employed to conduct an assessment of the path coefficients significance as explained by Hair et. al (2017). All hypotheses were supported at $p<0.01$ confidence level as depicted in Table 4 shows a summary of the structural model analysis.

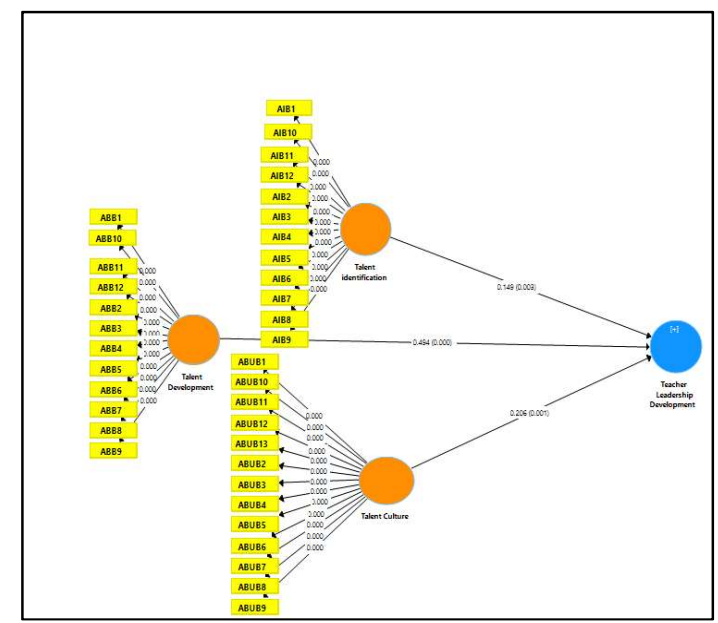

Fig. 3. Structural model assessment result

More specifically, Hypothesis $\mathrm{H}_{1}$ proposed the relationship between talent culture and teacher leadership. The obtained result supported the hypothesis at $(\mathrm{t}=3.436, \mathrm{p}<0.01)$. Then $\mathrm{H}_{2}$ relationship between talent development is supported the hypothesis at $(\mathrm{t}=6.746, \mathrm{p}>0.01)$. Lastly, the result exhibited in Table 5 and Fig. 3 supported Hypothesis 3 at $(t=2.967, p<0.01)$.

Table 45

Summary coefficient of determination result

\begin{tabular}{lcc}
\hline & R Square & R Square Adjusted \\
\hline Teacher Leadership & 0.639 & 0.636 \\
\hline
\end{tabular}

The assessment level of $\mathrm{R}^{2}$, Coefficient of Determination measuring model's accuracy was based on both exogenous and endogenous construct. Statistically, this assessment range was between 0 to 1 in explaining the level of accuracy between the association of exogenous and endogenous

\section{Discussion and Conclusions}

Findings of this study corroborate prior studies, which indicate that talent management affects teacher leadership development in secondary schools. This is in line with the study by Shuhaida (2017) that 
talent management was proposed to stimulate follower's teacher leadership development through expressing an inspiring vision, stimulating followers to question the status quo, and allowing individual development and growth. It has been argued to entail aligning followers' needs and desires with the interests of the organization (Bass,1999). The findings of this study also support the previous studies on significant relationship between talent management and leadership (Shuhaida 2016; Sathiyabama 2017). Similarly, this study is consistent with previous studies on a positive relationship between talent management and teacher leadership. The finding also shows that the talent identification, talent development and talent culture were positively related to teacher leadership development. Principal may contribute to increasing teachers' retention by valuing the teachers with compliment for performing well and the principals must always encourage teachers to collaborate with external networks to gain new ideas and perspectives to shares with their colleagues at the schools' site and support for innovation and transformation in teaching. In conclusion, this study was conducted to identify the gap in the study and to detect the instruments of high reliability and reliability so that the results of the study were of high quality to be used in the development of national education. The findings were critically synthesized to develop the talent management and teacher leadership model. This article contributed to our understanding and knowledge on the implementation of talent management dimension in secondary schools and functions as a point that will stimulate to the further research exploring the contextual aspects of talent management in education sector.

\section{References}

Ab Samad, R. S., Wahab, H. A., Sukor, M. I. R., \& Wei, L. Y. (2017). Contribution of headmaster transformational leadership towards teacher's sense of efficacy in under-enrolled primary schools in port Dickson. Malaysian Online Journal of Educational Management, 4(4), 66-80.

Annual Report (2015). Malaysia Education Blueprint 2013-2025. Ministry of Education.

Bass, B. M. (1999). Two decades of research and development in transformational leadership. European Journal of Work and Organizational Psychology, 8(1), 9-32.

Bersin, J. (2006). Talent management: What is it? Why now. Sinclair Consulting Inc, Morristown, NJ, USA.

Beheshtifar, M., Ali-Nezhad, H., \& Nekoie-Moghadam, M. (2012). Investigation of perceived organizational support on employees' positive attitudes toward work. Interdisciplinary Journal of Contemporary Research in Business, 4(8), 432-442.

Behrstock, E., \& Clifford, M. (2009). Leading Gen Y teachers: Emerging strategies for school leaders. TQ Research\&Policy BRIEF, Washington, DC, USA.

Charan, R., Drotter, S., \& Noel, J. (2010). The Leadership Pipeline.: How to Build the Leadership Powered Company(Vol. 391). John Wiley \& Sons.

Chen, J., Ou, L., Hillman, K., Flabouris, A., Bellomo, R., Hollis, S. J., \& Assareh, H. (2014). The impact of implementing a rapid response system: a comparison of cardiopulmonary arrests and mortality among four teaching hospitals in Australia. Resuscitation, 85(9), 1275-1281.

Davies, B \& Davies, B. J. (2011). Talent management in education. Sage Publications Ltd., London.

Fornell, C., \& Larcker, D. F. (1981). Evaluating structural equation models with unobservable variables and measurement error. Journal of Marketing Research, 18(1), 39-50.

Frost, D., \& Durrant, J. (2002). Teachers as leaders: Exploring the impact of teacher-led development work. School Leadership \& Management, 22(2), 143-161.

Gay, M, \& Sims, D. (2006). Building tomorrow's Talent: A practioner's guide to talent management and succession planning. Bloomington, IN: Author House

Greenlee, B. J (2007). Building teacher leadership capacity through educational leadership programs. Journal of Research for Educational Leaders. 4(1) 4474

Harris, A. (2003) Teacher leadership as distributed leadership: Heresy, fantasy or possibility? School Leadership and Management, 23(3), 313 - 324. 
Hair, J.F., Hult, G.T.M., Ringle, C.M., \& Sarstedt, M. (2017). A Primer Partial Least Squares Structural Equation Modelling (PLS-SEM). $2^{\text {nd }}$ edition. Los Angeles, London, New Delhi, Singapore, Washington DC, Melbourne. Sage Publications Inc.

House, R. J. (1971). A path goal theory of leader effectiveness. Administrative science quarterly, 16(3), 321-339.

Iles, P., Preece, D., \& Chuai, X. (2010). Talent management as a management fashion in HRD: Towards a research agenda. Human Resource Development International, 13(2), 125-145.

Katzenmeyer, M., \& Moller, G. (2009). Awakening the sleeping giant: Helping teachers develop as leaders. Corwin Press.

Leithwood K. A., Jantzi, D., \& Steinbach, R. (1999). Changing leadership for changing times. Buckingham, UK: Open University Press

Lewis, R. E., \& Heckman, R. J. (2006). Talent management: A critical review. Human resource management review, 16(2), 139-154.

Malaysia Education Blueprint 2013-2025, Ministry of Education

Michaels, E., Handfield-Jones, H., \& Axelrod, B. (2001). The war for talent: Harvard Business Review Press

Hamzah, M., Izham, M., \& Shamsudin, S. Talent Management and Teacher Leadership Talent Development in High Performing School in Malaysia. International Journal of Educational Best Practices, 1(1), 19-35.

Riccio, S. J. (2010) Talent Management in higher Education: identifying and developing emerging leaders within the administration at private college and universities. ProQuest, UMI Dissrtation publishing. (UMI Number:3409353)

Rhodes, C., \& Brundrett, M. (2005). Leadership succession in schools: A cause for concern. Management in Education, 19(5), 15-18.

Rhodes, C., \& Brundrett, M. (2009). Growing the leadership talent pool: Perceptions of heads, middle leaders and classroom teachers about professional development and leadership succession planning within their own schools. Professional Development in Education, 35(3), 381-398.

Rhodes, C., Brundrett, M., \& Nevill, A. (2008). Leadership talent identification and development: Perceptions of heads, middle leaders and classroom teachers in 70 contextually different primary and secondary schools in England. Educational Management Administration \& Leadership, 36(3), 311335.

Sathiyabama S. (2017). Bakat Kepimpinan, Kepimpinan Halatuju sekolah Graduan Program Kelayakan Profesional Kebangsaan bagi Pemimpin Pendidikan (NPQEL). Tesis PhD . Universiti Malaya

Shuhaida S. (2016). Pengurusan Bakat di sekolah berprestasi Tinggi di Malaysia. Tesis PhD tidak diterbitkan. Universiti Kebangsaan Malaysia

Taylor, M., Yates, A., Meyer, L. H., \& Kinsella, P. (2011). Teacher professional leadership in support of teacher professional development. Teaching and Teacher Education, 27(1), 85-94.

The Gallup Organisation, (2004). www.gallup.com.

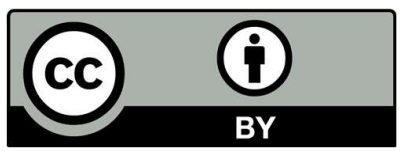

(C) 2020 by the authors; licensee Growing Science, Canada. This is an open access article distributed under the terms and conditions of the Creative Commons Attribution (CCBY) license (http://creativecommons.org/licenses/by/4.0/). 